\begin{tabular}{ll}
\hline \hline MINING AND METALLURGY INSTITUTE BOR & ISSN: 2334-8836 (Štampano izdanje) \\
UDK: 622 & ISSN: 2406-1395 (Online) \\
\hline \hline
\end{tabular}

UDK: 628.33:644.6:546.726.057(045)=111

doi:10.5937/mmeb1804049S

Danijela Simonović, Branka Pešovski*, Vesna Krstic ${ }^{*}$

\title{
ELECTROCHEMICAL SYNTHESIS OF FERRATE (VI) FOR THE WASTEWATER TREATMENT**
}

\begin{abstract}
Ferrate ion, $\mathrm{FeO}_{4}{ }^{2-}$ or $\mathrm{Fe}(\mathrm{VI})$, has long been known as a very powerful and environmentally benign oxidizing agent suitable for a wide range of applications: organic synthesis, water and wastewater treatment, corrosion protection, and as a cathode material in the new super iron batteries. Several technique have been developed for the synthesis of ferrates including the thermal, wet chemical and electrochemical. The electrochemical approach has received the most attention of the three synthesis methods because it is easier to perform, does not require harmful and costly chemicals and provides the possibility for continuous production. The electrochemical synthesis of ferrate (VI) is reviewed in this work. Particular attention is paid to the influence of factors such as the anode material, electrolyte composition, temperature and current density. Mechanism of ferrate synthesis and recent advances in this field are discussed as well.
\end{abstract}

Keywords: ferrate(VI), electrochemical synthesis, wastewater treatment

\section{INTRODUCTION}

Iron usually exists in the $0,+2$ and +3 oxidation state, however, it is possible to obtain the higher oxidation states of iron, theoretically up to +8 . These high oxidation states of iron are in the form of oxyanions, called ferrates, and the most stable is +6 or $\mathrm{FeO}_{4}{ }^{2-}$. Ferrate (VI) has a dark purple color similar to permanganate, $\mathrm{MnO}_{4}{ }^{2-}$.

Ferrate (VI) has been considered for years as a possible alternative to the most commonly used oxidants in the water treatment plants (chlorine, hydrogen peroxide and ozone). The unique characteristics of this compound are: high redox potential ( $\mathrm{E}=+2,2 \mathrm{~V}$, under acidic conditions), as well as the non-toxic by-product - Fe (III) hydroxide which has the properties of an effective coagulation agent. Therefore, in literature, ferrate (VI) is often called a “green" oxidant. In most cases, ferrate (VI) provide a complete degradation of the pollutants without harmless by-products.

The superior performance of ferrate (VI) as an oxidant/disinfectant and coagulant in water and wastewater treatment has been extensively studied. Separate laboratory studies have confirmed the ferrate (VI) efficiency in removal the various pathogenic microorganisms, bacteria [1], and viruses [2], among which are those resistant to chlorine. By comparing the disinfection ability of ferates and other oxidants, it can be concluded that ferrate (VI) exhibits the same or better effect even in smaller doses and shorter operating times.

Ferrate has also been proven to be a good pre-oxidant in the removal of algae and for a biofilm growth control. It has

\footnotetext{
* Mining and Metallurgy Institute, 35 Zeleni bulevar, 19210 Bor

** The authors are grateful to the Ministry of Education and Science of the Republic of Serbia for the financial support of the Project TR34004
} 
been demonstrated that many organic compounds can be easily oxidized by potassium ferrate. Alcohols, phenols [3-5], carboxyl compounds, amines, thiourea [6], thioacetamide, hydrazine and monomethyl hydrazine [7] are just some of them. Ferrate (VI) decomposes rapidly many recalcitrant pollutant such as antbiotics and endocrine disruptors.

Potassium ferate, thanks to its dual role, as an oxidizing agent and coagulant, can break down and remove a range of inorganic impurities in the treatment of wastewater. Some of these pollutants are: cyanides, ammonia, hydrogen sulphide [8], heavy metals $\left(\mathrm{Mn}^{2+}, \mathrm{Cu}^{2+}, \mathrm{Pb}^{2+}, \mathrm{Cd}^{2+}, \mathrm{Cr}^{2+}\right.$, and $\left.\mathrm{Hg}^{2+}\right)$ [9.10]. Removal of radioactive elements from wastewater with potassium ferate was also studied. In addition, potassium ferate is effective in oxidation of As (III) to As (V), and its subsequent removal by adsorption onto $\mathrm{Fe}(\mathrm{OH})_{3}$.

In the field of the corrosion protection, ferrate(VI) can be utilized for passivation of aluminum, zinc and iron products, or to dissolve the resistant deposits from the different metal surfaces [11].

In the organic synthesis, ferrate (VI) can be a substitute and safer alternative to the other highly toxic oxidizing compounds, e.g. $\mathrm{CrO}_{3}, \mathrm{~K}_{2} \mathrm{Cr}_{2} \mathrm{O}_{7}, \mathrm{KMnO}_{4}$.

Ferrate has also been used in a new class of environment-friendly high capacity batteries, referred to as the super-iron batteries, as cathode material instead of hazardousMnO $\mathrm{MnO}_{2}$ [12].

Generally, three kinds of technique are used to synthesize ferrate (VI): (i)wet chemical synthesis, implies oxidation of ferric compounds by hypochlorite in highly alkaline environment(ii) thermal chemical synthesis, implies oxidation of ferric compounds at high temperature in molten state with alkaline peroxide and (iii) electrochemical synthesis, implies anodic dissolution of iron or its alloys in strongly alkaline solution in the low trans-passive region of potential. Chemical synthesis of ferrate (VI) must be conducted under the strictly controlled conditions in consideration a danger of poisoning and explosion. The additional problem is a separation and purification of the obtained ferrate (VI), because the toxic oxy-chlorine compounds are always present [13].

The electrochemical technique is the most promising because it uses electrons as the "clean" reactants and produces a pure dissolved Fe (VI) product with better yields [14]. However, the obtained maximal concentration of $\mathrm{Fe}(\mathrm{VI})$ is limited by the low stability of $\mathrm{Fe}(\mathrm{VI})$ species and deactivation of the anode surface.

\section{ELECTROCHEMICAL SYNTHESIS}

The process of electrochemical generation of ferrate (VI) usually consists of a sacrificial iron anode in strongly alkaline solution with electric current serving to oxidize iron to Fe (VI), Eq. (1), while the hydrogen gas is generated on a cathode, Eq. (2) $[15,16]$ :

Anode reaction:

$\mathrm{Fe}+8 \mathrm{OH}^{-} \rightarrow \mathrm{FeO}_{4}{ }^{2-}+4 \mathrm{H}_{2} \mathrm{O}+6 \mathrm{e}$

Cathode reaction:

$3 \mathrm{H}_{2} \mathrm{O} \rightarrow 3 \mathrm{H}_{2}+6 \mathrm{OH}^{-}-6 \mathrm{e}$

Overall reaction:

$$
\begin{aligned}
& \mathrm{Fe}+2 \mathrm{OH}^{-} \rightarrow \mathrm{FeO}_{4}{ }^{2-}+3 \mathrm{H}_{2}+\mathrm{H}_{2} \mathrm{O} \\
& \mathrm{FeO}_{4}{ }^{2-}+2 \mathrm{~K}^{+} \rightarrow \mathrm{K}_{2} \mathrm{FeO}_{4} \\
& \quad \text { (in } \mathrm{KOH} \text { medium) }
\end{aligned}
$$

The electrochemical generation of ferrate is significantly affected by many factors, mainly, the anode composition, type and concentration of electrolyte, temperature and current density. Thus, many researchers have focused their attention on optimization of these parameters. These parameters influence the structure of passive layer and possibility of its dissolution during the electrochemical synthesis of ferrate. Parameters should be selected in such way to avoid blocking the anode surface with poorly soluble species. 


\subsection{Anode Material Composition}

Carbon content in the anode material has a crucial impact on the anode dissolution process. There is a general agreement that only carbon in the form of iron carbide $\left(\mathrm{Fe}_{3} \mathrm{C}\right)$ positively influences the anode material dissolution. White cast iron (WCI), containing 3.17 wt.\% of carbon in the form of $\mathrm{Fe}_{3} \mathrm{C}$ is a typical representative. For a grey cast iron (GCI), where carbon is present in a form of graphite, the efficiency of ferrate (VI) synthesis is even lower than for a pure iron anode. Graphite on the surface of the GCI anode lowers the over potential to the competing oxygen evolution reaction and reduces the current efficiency of the electrochemical process. On the contrary, the $\mathrm{Fe}_{3} \mathrm{C}$ readily dissolves in the concentrated $\mathrm{NaOH}$ exposing a fresh anode surface to the anolite. It was reported that the silicon content has the similar influence on the protective layer as iron carbide [17].

\subsection{Temperature}

The influence of temperature on the efficiency of electrochemical synthesis of ferrate (VI) has been studied from the earliest stage of research. There are two basic impacts of temperature on ferrate (VI) production. The first, rise in temperature increases the activity of $\mathrm{OH}^{-}$ions and their interaction with the oxo-hydroxide layer, thus accelerates de-passivation of anode. This is especially important for materials that tend to build a compact protective layer, such as pure iron. In contrast, using an anode material with a high iron carbide content such as white cast iron (WCI), the high yields can be achieved at $20^{\circ} \mathrm{C}$. The second, increase in temperature causes an enhancement in the rate of ferrate (VI) decomposition [17].

Conclusion is that by the appropriate selection of anode material and electrolyte composition, the effect of temperature on the efficiency of electrochemical synthesis of ferrate can be minimized.

\subsection{Electrolyte Composition}

The electrolyte composition and its concentration is one of the most important factors that affect the synthesis of ferrate (VI). It was found that using more concentrated $\mathrm{OH}^{-}$solution, both surface layer disintegration and ferrate (VI) stability are increased [17].

Stability of ferrate (VI) in a highly concentrated $\mathrm{NaOH}$ solution was investigated by L. Ding et al. Under these conditions, a ferrate ion undergo the spontaneous decomposition described by the following reaction, Eq. (5):

$2 \mathrm{FeO}_{4}{ }^{2-}+5 \mathrm{H}_{2} \mathrm{O} \rightarrow 2 \mathrm{Fe}(\mathrm{OH})_{3}+4 \mathrm{OH}^{-}+3 / 2 \mathrm{O}_{2} \uparrow$

A set of experiments was carried out with initial ferrate (VI) concentration of $0.145 \mathrm{mM}$ in aqueous $\mathrm{NaOH}$ solution with concentration in a range of $1.5-14 \mathrm{M}$. It was assumed that the reaction of ferrate (VI) decomposition follows the first order kinetics. A decomposition rate constant $\mathrm{k}_{\mathrm{d}}$ and half-life of ferrate (VI) in different $\mathrm{NaOH}$ solutions were calculated. These results demonstrated a great effect of $\mathrm{NaOH}$ concentration on the aqueous decomposition of ferrate (VI). Free water activity in $\mathrm{NaOH}$ solution from $1.5 \mathrm{M}$ to $14 \mathrm{M}$ decreases and inhibits the redox reaction Eq. (6). For example, a half-life of ferrate (VI) in $1.5 \mathrm{M}$ $\mathrm{NaOH}$ was found to be $0.48 \mathrm{~h}$, in $8 \mathrm{M}$ $\mathrm{NaOH}$ ten times longer $4.8 \mathrm{~h}$, but in $14 \mathrm{M}$ $\mathrm{NaOH}$ was greatly extended to even $43 \mathrm{~h}$ $[18,19]$.

Numerous researches reported a maximum current efficiency of ferrate (VI) generation in $14 \mathrm{M} \mathrm{NaOH}$ solution. Further increase in $\mathrm{NaOH}$ concentration causes a decrease in current efficiency and ferrate (VI) yield. When the concentration of sodium hydroxide approaches to its saturated value of around $20 \mathrm{M}$, the electrolyte solution will become very viscous and solution conductivity will decline significantly resulting in a lower rate of electron transfer on the anode surface and ferrate (VI) generation [20]. 


\subsection{Mechanism}

Although $\mathrm{NaOH}$ is the leading electrolyte for electrochemical preparation of ferrate, the electrolyte solution may include a hydroxide selected from potassium hydroxide, lithium hydroxide, cesium hydroxide, barium hydroxide and combinations between them [15]. It was reported that when comparing $\mathrm{LiOH}, \mathrm{NaOH}$ and $\mathrm{KOH}$ solutions, the $\mathrm{NaOH}$ solution provides the highest ferrate and current yields [21]. On the contrary, He et al. [8] reported that $\mathrm{KOH}$ is far better electrolyte for electro-sinthesizing ferrate (VI) than $\mathrm{NaOH}$. The results showed that under the similar conditions, the obtained current efficiency in the concentrated $\mathrm{NaOH}$ solution was $55 \%$, while it could reach $73.2 \%$ in a solution of $\mathrm{KOH}$ for temperature higher than $50^{\circ} \mathrm{C}$. Ferrate produced in $\mathrm{KOH}$ was more stable and with purity.

\subsection{Other Important Synthesis Parameters}

Anode activation before or during the electrolysis significantly improve ferrate (VI) synthesis efficiency. The following methods have been proposed for this purpose: mechanical polishing, chemical etching, ultrasound and cathodic pre-polarization.

Anode geometry is another important factor in the electrochemical synthesis of ferrate. Generally, increasing the specific surface area of the anode yields a significant enhancement of production rates. Several authors reported the utilization of threedimensional iron anodes in a form of iron wire gauze $[22,23]$, porous magnetite electrode [24], pressed iron powder [12,24], iron chunks [25], and sponge iron [20].

The efficiency of ferrate (VI) formation is also affected by the electrolysis time. Increasing the electrolysis time will decrease the amount of ferrate (VI) due to a decomposition, and anode deactivation. This represents a serious hurdle for the industrial continuous production [17].
The anodic behavior of an iron electrode in alkaline solutions has been studied in detail by numerous authors. The reason of an intensive research of this system were mainly the investigation of corrosion protection and improvement the construction of alkaline Ni-Fe cells. More recently, a trend in ferrate (VI) research has turned from optimization of electrochemical production toward a deeper understanding of the electrode reaction mechanism $[26,17]$.

Anodic dissolution of iron takes place in several successive processes. Various feroand ferric oxides, hydroxides and oxihydroxides are formed on the anode surface, among which the ferric compounds are particularly poorly soluble and lead to the anode passivation. With an increase in anodic potential the conditions for formation of soluble compounds of iron in higher valence state are obtained, i.e. trans passive dissolution $[17,27]$.

Voltametric studies of iron behavior in the alkaline media exhibit several peaks and shoulders within the potential range of water stability, corresponding to the active dissolution of anode material and surface layer restructuring. The anodic current peak $\mathrm{a}_{1}$ at a potential of about $-0.1 \mathrm{~V}$ (depends on the electrolysis conditions and electrode composition) corresponds to the active iron dissolution to $\mathrm{Fe}^{2+}$ according to Eq. (6). Oxidation reactions, Eqs. $(7,8)$, may occur simultaneously $[17,13,26]$ :

$$
\begin{aligned}
& \mathrm{Fe}+2 \mathrm{OH}^{-} \rightarrow \mathrm{Fe}(\mathrm{OH})_{2}+2 \mathrm{e}^{-} \\
& 3 \mathrm{Fe}+8 \mathrm{OH}^{-} \rightarrow \mathrm{Fe}_{3} \mathrm{O}_{4}+4 \mathrm{H}_{2} \mathrm{O}+8 \mathrm{e}^{-} \\
& \mathrm{Fe}+2 \mathrm{OH}^{-} \rightarrow \mathrm{FeO}+\mathrm{H}_{2} \mathrm{O}+2 \mathrm{e}^{-}
\end{aligned}
$$

Current peak $\mathrm{a}_{2}$, corresponds to a continuous oxidation of $\mathrm{Fe}(\mathrm{OH})_{2}$ to $\mathrm{Fe}_{3} \mathrm{O}_{4}$, according to Eq.(9). Parallel oxidation of $\mathrm{Fe}_{3} \mathrm{O}_{4}$ is possible, according to Eq.(10) $[13,26]$ :

$$
\begin{aligned}
& 3 \mathrm{Fe}(\mathrm{OH})_{2}+2 \mathrm{OH}^{-} \rightarrow \mathrm{Fe}_{3} \mathrm{O}_{4}+4 \mathrm{H}_{2} \mathrm{O}+2 \mathrm{e}^{-} \\
& \mathrm{Fe}_{3} \mathrm{O}_{4}+2 \mathrm{H}_{2} \mathrm{O} \rightarrow 3 \mathrm{FeOOH}+\mathrm{H}^{+}+\mathrm{e}^{-}
\end{aligned}
$$


It is assumed that the reactions of passive layer with $\mathrm{OH}^{-}$ions, Eqs. (11-13), causes the iron surface to break down and enables continuous dissolution of the anode, corresponds to the current peak $\mathrm{a}_{3}[1,14]$.

$$
\begin{aligned}
& \mathrm{Fe}(\mathrm{OH})_{2}+2 \mathrm{OH}^{-} \rightarrow \mathrm{FeO}_{2}{ }^{2-}+2 \mathrm{H}_{2} \mathrm{O} \\
& \mathrm{Fe}_{3} \mathrm{O}_{4}+4 \mathrm{OH}^{-} \rightarrow 3 \mathrm{FeO}_{2}{ }^{-}+2 \mathrm{H}_{2} \mathrm{O}+\mathrm{e}^{-}
\end{aligned}
$$

$$
\mathrm{Fe}_{2} \mathrm{O}_{3}+2 \mathrm{OH}^{-} \rightarrow 2 \mathrm{FeO}_{2}^{-}+\mathrm{H}_{2} \mathrm{O}
$$

After the active dissolution region, a broad passivity plateau follows. At the potential of about $0.6 \mathrm{~V}$, the oxygen evolution commence, Eq. (16). At the same time, the oxidation reaction, Eq.(14), takes place, followed by the subsequent dispro-portionation reaction, Eq. (15). Peak $\mathrm{a}_{4}$ the corresponds to the reactions (14-16) cannot always be observed because an intensive oxygen evolution overlaps the trans-passive iron dissolution, including ferrate (VI) formation $[17,13]$.

$$
\begin{aligned}
& \mathrm{FeOOH}+3 \mathrm{OH}^{-} \rightarrow \mathrm{FeO}_{3}{ }^{2-}+2 \mathrm{H}_{2} \mathrm{O}+\mathrm{e}^{-} \\
& 3 \mathrm{FeO}_{3}{ }^{2-}+\mathrm{H}_{2} \mathrm{O} \rightarrow 2 \mathrm{FeO}_{2}{ }^{-}+\mathrm{FeO}_{4}{ }^{2-}+2 \mathrm{OH}^{-} \\
& 2 \mathrm{OH}^{-} \rightarrow \mathrm{H}_{2} \mathrm{O}+1 / 2 \mathrm{O}_{2}+2 \mathrm{e}^{-}
\end{aligned}
$$

During the negative scan of the potential, the three cathodic current peaks are often observed and attributed to the reduction of $\mathrm{Fe}(\mathrm{VI})$ to $\mathrm{Fe}$ (III), $\mathrm{Fe}$ (III) to $\mathrm{Fe}(\mathrm{II})$, and $\mathrm{Fe}(\mathrm{II})$ to $\mathrm{Fe}(0)$ [13].

\section{THE NEW APPROACHES IN THE ELECTROCHEMICAL SYNTHESIS OF Fe(VI)}

Ferrate can be synthesized by the oxidation of ferric ion with an inert electrode ( $\mathrm{Pt}$, $\mathrm{BDD}, \mathrm{SnO}_{2}-\mathrm{Sb}_{2} \mathrm{O}_{3} / \mathrm{Ti}$ ) as well as in hydroxide melts by the oxidation of an iron anode.

In recent years, the electrochemical oxidation with conductive diamond anodes converted into very promising technology for electro synthesis of powerful oxidants such as peroxodisulfates, peroxsodifosfates and percarbonates. Electrochemical generation of ferrate (VI) using BDD (boron- doped diamond electrode) was successfully performed by Canizares et al. [28,29]. Within this research research, it was demonstrated that the application of ultrasound and iron powder as the raw material during the electrochemical synthesis of ferrate using conductive diamond electrode, enhances the efficiency of process. While high current density and hydroxide concentration increase the yield and stability of the generated ferrate product [29].

The formation of ferrate (VI) in molten $\mathrm{NaOH}-\mathrm{KOH}$ system was studied by Hiveš et al. [30,11]. The most important advantages of these method are: (1) there is no decomposition of the resulting ferrate due to the absence of water in electrolyte, (2) after cooling down of the reaction mixture, ferrate (VI) is in a solid dry form and thus stable, (3) lack of passive layer formation on the iron electrode, (4) chemical step in the ferrate (VI) formation mechanism is accelerated by raise the operational tempe-rature of electrolysis.

The main issue in this synthetic approach that requires attention is the stability of ferrate (VI) product at the temperature of a suitable molten hydroxide mixture (170 $200^{\circ} \mathrm{C}$ ). Therefore, this group of authors chose the eutectic mixture of the $\mathrm{NaOH}$ $\mathrm{KOH}(51,5 \mathrm{~mol} \% \mathrm{NaOH})$, characterized by a relatively low eutectic melting point of $170^{\circ} \mathrm{C}$ and high electrical conductivity of $0.588 \Omega^{-1} \mathrm{~cm}^{-1}$.

\section{CONCLUSION}

It has been demonstrated by numerous studies that ferrate (VI) is one of the most powerful oxidants for water and wastewater treatment. However, the challenges have still existed to the implantation of ferrate (VI) technology in practice due to poor stability of Fe (VI) solutions and high cost of the solid ferrate salts as they require costly chemicals and multiple purification steps.

Of the three synthesis methods - electrochemical, chemical and thermal, the electrochemical method is the most promi-sing due to its simple performance, high 
purity of product and absence of hazardous chemicals. Many factors affect the electrochemical ferrate (VI) production, such as anode composition, type and concentration of electrolyte, temperature, cell design, etc. Further work on optimization of these parameters is necessary. Although the electrochemical generation of ferrate (VI) has been known for almost two centuries and many advances have been made over this period, there are still many unresolved questions that should be overcome, such as: passivation of the anode surface during the electrolysis, self-decomposition and low yields of ferrate product. It can be concluded that ferrate (VI) represents vital and continuing field of research.

\section{REFERENCES}

[1] J.Q. Jiang, S. Wang, A. Panagoulopoulos, Desalination 210 (2007) 266-273

[2] J. Ma, W. Liu, Water Research 36 (2002) 871-878

[3] M. Lim, M.J. Kim, Water Air Soil Polution 200 (2009) 181-189

[4] H. Huang, D. Sommerfeld, B. Dunn, E.M. Eyring, C. Lloyd, Journal of Physical Chemistry A 105 (2001) 35363541

[5] Y. Lee, J. Yoon, U. Von Gunten, Environ.Sci.Technol. 39 (2005) 8978-8984

[6] J. Q. Jiang, S. Wang, A. Panagoulopoulos, Desalination 210 (2007) 266-273

[7] M. Johnson, B. Hornstein, Inorganica Chimica Acta 225 (1994) 145-150

[8] V. Sharma, J. Smith, F. Millero, Environ. Sci. Technol. 31 (1997) 2486-2491

[9] J.Q. Jiang, S. Wang, A. Panagoulopoulos, Chemosphere, 63 (2006) 212-219

[10] M. Lim, M. Kim, Water Air Soil Pollut, 211 (2010) 313-322

[11] L. Hrnčiarikova, M. Gal, K. Kerekeš, J. Hiveš, Electrochimica Acta 110 (2013) 581-586

[12] M. De Koninck, D. Belanger, Electrochimica acta 48 (2003) 1435-1442

[13] Lj.N. Bujanović, M. Čekerevac, M.V. Miloradov, Journal of Industrial and
Engineering Chemistry 18 (2012) 1931-1936

[14] V.K. Sharma, Z. Macova, K. Bouzek, F.J. Millero, J.Chem. Eng. Data 55 (2010) 5594-5597

[15] M. Alsheyab, J.Q. Jiang, C. Stanford, Journal of Environmental Management, 90 (2009) 1350-1356

[16] M. Alsheyab, J.Q.Jiang, C.Stanford, Desalination, 254 (2010) 175-178

[17] Z. Macova, K. Bouzek, J. Hiveš, V. Sharma, R.J. Terryn, J.C. Baum, Electrochimica Acta 54 (2009) 2673-2683

[18] L. Ding, H.C. Liang, X.Z. Li, Separation and Purification Technology 91 (2012) 117-124

[19] E. L. Yang, J.J. Shi, H.C. Liang, Electrochimica Acta 63 (2012) 369-374

[20] X. Sun, Q. Zhang, H. Liang, L. Ying, M. Xiangxu, V. Sharma, Journal of Hayardous Materials

[21] K. Bouzek, M. Schmidt, A. Wragg, Electrochemistry Communications 1 (1999) 370-374

[22] W. He, J. Wang, H. Shao, J. Zhang, C. N. Cao, Electrochemistry Communications 7 (2005) 607-611

[23] W. He, J. Wang, C. Yang, J. Zhang, Electrochimica Acta 51 (2006) 1967-1973

[24] Z. Ding, C. Yang, Q. Wu, Electrochimica Acta 49 (2004) 3155-3159

[25] V. Lescuras-Darrou, F. Lapicque, G. Valentin, Journal of Applied Electrochemistry, 32 (2002) 57-63

[26] K. Bouzek, I. Roušar, H. Bergmann, K. Hertwig, Journal of Electro-analytical Chemistry 425 (1997) 125-137

[27] M. Čekerevac, Lj. Nikolić-Bujanović, M. Simičić, Hemijska Industrija 63 (5) (2009) 387-395

[28] P. Canizares, M. Arcis, C. Saez, M.A Rodrigo, Electrochemistry Communications 9 (2007) 2286-2290

[29] A. Sanchez-Carretero, M.A. Rodrigo, P. Caniyares, C. Saez, Electro-chemistry Communications 12 (2010) 644-646

[30] J. Hiveš, M. Benova, K. Bouzek, J. Sitek, V.K. Sharma, Electrochimica Acta 54 (2008) 203-208 